\title{
The implication of Baduy Dalam tribe's closure on Indonesia's rank in the World Economic Forum
}

\author{
Anwar Soleh Purba*, Achmad Hufad, Chandra Perwira Negara, Nasrawati Nasrawati, Alif Melky Ramdani \\ Universitas Pendidikan Indonesia \\ Bandung, Indonesia \\ *Anwarsolehpurba12@gmail.com
}

\begin{abstract}
Education, health, technology and infrastructure are important factors for improving the status of the Indonesian state in international forums such as the World Economic Forum (WEF). The dropping of some ethnic groups in Indonesia certainly has an impact on the forum. The purpose of this study is to find out the information of deeply built Baduy ethnic will be education and even health and technology of course. As this research use qualitative method, case study type and data collection through observation, documentation study and interview on some village leaders and its population. As the result of research findings, that is: 1) Closure of Bedouin tribe against Formal education, 2) Inner Ethnic in still closed access to health, 3) Inner Baduy, still covered by technology and infrastructure development. Ethnic Baduy Dalam is an ethnic group that is covered with culture from outside. so, ethnic Baduy Dalam was introduced as Ethnic who still Original Culture in Modern era at this time.
\end{abstract} forum

Keywords-baduy tribe; government concern; world economic

\section{INTRODUCTION}

According to Saini local wisdom is often associated with local communities. In a foreign language it is conceptualized as local wisdom, local knowledge, or local genius [1]. as local wisdom Baduy Dalam tribe is also a traditional ethnic which of course we have to keep our guard as an asset of this nation. Global education has always been debated and studied because the development and progress of the world has led to modernization. Although global education involves different approaches and conceptualizations, it has had an impact on education and curriculum systems around the world [2]. Today, people need to be ready to face globalization. Of course, it requires the competences in digital and cultural integration to become successful global citizens [3]. There is a general difference between globalization and internationalization. Globalization is seen as a socially curved process of economics wherein internationalization is understood as the way in which educational institutions respond to globalization [4]

The interesting thing about Baduy society is their local wisdom about the view of the universe. Baduy society is very balancing and in harmony with nature. Therefore, the Baduy people are very guarding the teachings about preserving nature and preserving. This is what creates the Baduy community coexist with nature in harmony. Other than that. Baduy people do not exploit nature, they use as necessary in nature and accompanied by preservation. The process of globalization produces the World Economic Forum (WEF) as a forum in encouraging the improvement of the quality of a country towards the global community. Thus, every qualified country in prospering the people will gain the trust of other countries to establish a cooperation [5]. The forum may reflect the most exclusive trans-national type in which it will result in an agreement with the top political figures to discuss each country's development [6].

In accordance with the demands, education becomes one of the most central aspect of attention. So, every country should provide learning opportunities for everyone [7]. Given that the main characteristic of the twenty-first century is globalization itself. Global education must be embedded in the discourse of the twenty-first century along with the competence used by the policymakers around the world. Thus, global education becomes an important subject like integrated human rights [8]

It is in line with the educational discussion that must be realized and will support the development of ethnic hierarchy and rights. Thus, the process of inclusion and exclusion seems to form the basis of a universal hegemonic citizenship vision [9] that will bring up a complex social force, such as ethnic nationalism and cultural romanticism among the people. The most remarkable development is the exclusive use of land as a symbol of identity and ethnicity of the homeland. It is because land that has been inherited will be settled as part of the ancestors' land to be maintained [10].

It involves the fact that facing a dilemma concerning the identity of gratuity and racial education is influenced by politics that encourages people to teach racial identity to avoid the reality of racialized system of power. So, they are obliged to respect their ethnic epistemic obligations [11]. According to this construct, in order to understand one's aspect of self, we must understand how gender, ethnicity, sexuality, social class, and others influence one another [12]. That becomes one of the problems faced by the government in an ordered society welfare.

There are often health problems in rural areas that require social workers who have generalist knowledge and training in a variety of theories and skills, especially in evidence-based care and crisis intervention [13]. In addition to medical personnel who are reluctant to plunge into the inside system, a tribe itself 
does not receive healthcare. The more modern health institutions are expected to not only contribute to the knowledge and understanding of ethnicity abuse, but also allow us to appreciate special personal and professional qualities [14].

The problems of the lack of healthcare supply, education, infrastructure development, and technology get the tribe become a lagging tribe. However, such uniqueness is certainly not a problem for them. It will only affect Indonesia's downgrades in the International Economic Forum and lead to a reduction of foreign investor confidence to work with Indonesia. This is certainly because of the people's welfare which is not equitable. Research will be a source of knowledge for the government to prioritize cultural wealth. our country Indonesia does not have to compete thoroughly with other countries. The Indonesia nation must rely on what its natural wealth and culture. Such as the Baduy Dalam ethnic culture. we must retain to the originality of Baduy Dalam tribe so that this ethnic remains an asset for this nation. by explaining the ethnic Bedouin Inu through this article is expected to be a new knowledge for the world community and will increase the income from the tourism sector.

\section{RESEARCH METHOD}

This research used descriptive qualitative approach through in-depth literature review. Qualitative research is a research procedure that produces descriptive data in the form of written or oral words of people and behaviors that can be observed. [15]. While, the literature review is used as a strengthening way related to Baduy Dalam. Paper will explain how the life system of Baduy tribe in. this will be associated with the inaccuracy of Baduy tribe in to the outside world. Because it the outside world is considered to damage the original culture of Baduy tribe in. by not receiving formal education, technology and medical experts is considered as one way to maintain the culture. The participant in this research were the community leaders and some residents of Baduy Dalam and Baduy Luar.

Thus, qualitative approach will help the researchers know how the people maintain their identity. The globalization era is increasingly leading to progress, while endangering the original values and identity. The World Economic Forum demands that each of the countries incorporated in it pays attention to the prosperity of its people. In addition, the researchers also conducted data triangulation to deepen the results about Baduy Dalam tribe.

\section{DISCUSSION}

World Economic Forum becomes one of the institutions established to know how the development of each country incorporated therein. It is incomplete to discuss the understanding of each tribe if the Baduy Dalam and Baduy Luar tribes are excluded. Until now, the Baduy Dalam tribe still adheres to the values of beliefs and customs of their ancestors, so that their culture is difficult to be influenced by the outside world. The tribe is often divided into two groups by the people outside the region into the Baduy Dalam tribe and Baduy Luar tribe. However, Baduy people themselves think that there is only one Baduy. Baduy tribe belongs to Sundanese ethnic living together and synergizing with nature in the region of Banten, precisely in Kendeng mountain, Kanekes village, Lebak regency.

Until now, the people still hold strongly the concept of pikukuh (customary rules that are the most important teaching in the community) in daily life, so that many taboos are still very strictly enforced. The Baduy Dalam and Baduy Luar tribes are different each other characterized by quite a lot of aspects, especially regarding abstinence obeyed by the people. Viewed from the appearance, the Baduy Luar people wear black or dark-blue clothes to declare that they are no longer sacred. Meanwhile, the Baduy Dalam people wear white clothes. The Baduy Dalam people are still closed from the use of technology like mobile phone, television, and so forth because it becomes the customary abstinence to use technology-based communication tools. However, the Baduy Luar people have already recognized technology in the form of electronic devices, despite the customary restrictions.

Until now, the tribe of Baduy Dalam also maintain the customary system in the use of transportation. For example, they do not use all vehicles, despite the long distance they should go through. Meanwhile, the Baduy Luar people have started thinking and used vehicles, like motorcycles and cars. The former will prefer to walk even though miles should be gone through. In addition, the Baduy Dalam people still use traditional tools without using motor power to do things, such as: cleaning the garden, working in rice fields, and so forth.

In the educational system of Baduy Dalam tribe, they are not familiar with the formal educational system like schools. The children are only educated about how to live in nature. Education for them has been inculcated from childhood taught by their parent about the traditions of being modest, having kinship through cooperation (gotong royong), and being able to do main things like farming or weaving. It is all for the survival of the Baduy Dalam tribe. The World Economic Forum demands every country to provide equal educational system to its people because every human being has a right to obtain any learning. If it is not fulfilled, then the country will get a strong warning by other countries within the international forum. The Baduy Luar people who have modern thinking are expected to influence the Baduy Dalam people to receive education as part of ethnic progress. This is certainly because it will impact on Indonesia's rank in international forums. However, the problem is they already felt comfortable with the current situation. Although education is not noticed by the government, it is certainly not a problem for the people of Baduy Dalam.

Baduy tribe is closed from the outside world because they fear of others capturing the wealth of their tribe and want to protect the community. Such circumstance leads to the inability of Baduy Dalam people to read and write, thus affecting the negative thinking on technology. In addition, they do not want to communicate with outsiders who want to share knowledge and want to give understanding that the existing technology can help them preserve their own culture and community. Their ancestors tell them that the outside world is not good, so such philosophy is still influential until now. The beliefs of Baduy Dalam people on traditional medicine and closed to modern 
treatment through medical personnel lead to an increasing number of deaths. So, the prosperity of Indonesian society is considered not good in international forum. So this will affect Indonesia's ranking in international forums. Obviously, it will have an impact on the lack of confidence of foreign investors in Indonesia and will certainly cause harm to Indonesia.

\section{CONCLUSION}

To promote the status of Indonesia in the World Economic Forum, surely the government should prosper the citizens. It becomes the benchmark in international forums in terms of educational, health, technological, tourism, and infrastructure quality. The Baduy Dalam tribe becomes one of the tribes who is still closed to the outside world. They consider that preserving the nature is the only thing to do because they live from nature and will be back to nature. They believe that the outside cultures will harm the nature. They only need to teach their children how to farm, preserve the nature, and cooperate with other people. Besides, the Baduy Dalam tribe does not accept technology because they think that technology only harms the nature. Likewise, in terms of health sector, Baduy Dalam people still use traditional treatment and medicine. They still believe that nature is better in providing treatment. Therefore, the main problem lies on if a country lacks of ability to pay attention to its citizens in terms of education, technology, infrastructure, and health, it will impact on the decrease of Indonesia's rank in the World Economic Forum (WEF) and on the decrease of interest for the foreign investors to cooperate with Indonesia.

\section{REFERENCES}

[1] E.P. Cecep, Local wisdom of Baduy people in disaster mitigation, Jakarta: Wedatama Widya Sastra, 2010.

[2] Açikalin, and Mehmet, "The Influence of Global Education on the Turkish Social Studies Curriculum,” The Social Studies, 2010.

[3] Camilleri, "Global education and intercultural awareness in eTwinning, Teacher Education and Development, 2016.

[4] Maldonado, and Cantwell, "Four stories: confronting contemporary ideas about globa- lisation and internationalisation in higher education," Globalisation, Societies and Edu- cation, vol. 7, No. 3, 2009.

[5] H. Chartrand, "Art, Culture, and Global Business-Snapshots from the World Economic Forum," The Journal of Arts Management, Law, and Society, vol. 22, No.1, 2010.

[6] J.C. Graz, "How Powerful are Transnational Elite Clubs? The Social Myth of the World Economic Forum," New Political Economy, vol. 8, No. 3, 2003.

[7] S. Gopinathan, "Globalisation, the Singapore developmental state and education policy," Globalisation, Societies and Education, vol. 5, No. 1, 2007.

[8] S. Choo Suzanne, "Global education and its tensions: case studies of two schools in Singapore and the United States," Asia Pacific Journal of Education, 2018.

[9] Tsimouris, and Kirtsoglou, "Migration, crisis, liberalism: the cultural and racial politics of Islamophobia and "radical alterity" in modern Greece," Ethnic and Racial Studies, 2018.

[10] L. Haokip, "Culture, ethnicity and territoriality: a cultural history of imagined land in Manipur," Asian Ethnicity, 2018.

[11] Thomson, "Reconstructing a 'Dilemma' of racial identity education," Ethics and Education, 2018.

[12] Rozas, and Garran, "Cultural Competence Revisited," Journal of Ethnic And Cultural Diversity in Social Work, vol. 22, pp. 97-111, 2013.

[13] Beecher, and Blake, "An exploration of social work needs of select rural behavioral health agencies in Washington state," Social Work in Mental Health, vol. 14, No.6, pp. 714-732, 2016.

[14] A. Gordon A, "Foreword: Ethnographic methods in the study of ethnicity in substance abuse," Journal of Ethnicity in Substance Abuse, vol. 17, No. 1, pp. 1-6, 2018.

[15] Moleong, and Lexy, Qualitative research methods, Bandung : Remaja Rosdakarya, 2012. 